\title{
Säähavainto- ja sääennustetieto kasvinsuojelun apuna
}

\author{
Hanna Huitu ${ }^{1}$, Marja Jalli ${ }^{1}$, Frederick Teye ${ }^{1}$, Pasi Suomi ${ }^{1}$, Sirpa Thessler $^{1}$, Raimo Linkolehto ${ }^{1}$, \\ Patrik Erlund ${ }^{2}$ \\ ${ }^{I}$ Maa-ja elintarviketalouden tutkimuskeskus MTT \\ ${ }^{2}$ Nylands Svenska Lantbrukssällskap
}

\section{Tiivistelmä}

Keväällä päättyvässä EnviSense-hankkeessa (Kannattavuutta ja lisäarvoa maatalouteen ympäristön automaattisesta reaaliaikaisesta seurannasta ja siihen pohjautuvista neuvontapalveluista) on rakennettu automaattista mittaustietoa hyödyntäviä sovelluksia peltoviljelyn tarpeisiin. Tässä esittelemme kaksi pilottia: 1) kasvinsuojeluennusteiden tarkentaminen automaattisella, paikallisella mittaustiedolla, ja 2) säätiedon tuominen kasvinsuojeluruiskun tehtävänhallintaan. Piloteissa demonstroidaan säähavainto- ja sääennustetiedon hyödyntämistä sovelluksissa sekä selvitetään paikallisen, jatkuvatoimisen mittaamisen haasteita ja etuja. Piloteissa hyödynnettiin Maasäämittausverkoston automaattisia sääasemia, jotka sijaitsevat Karjaanjoen valuma-alueen maatiloilla. Lisäksi sääasemia pystytettiin maatalousoppilaitosten ja viljelijöiden peltolohkoille Hämeeseen, Pohjanmaalle ja läntisen Uudenmaan rannikolle. Asemat mittaavat ilman lämpötilaa ja kosteutta, sademäärää sekä tuulen suuntaa ja nopeutta 15 minuutin välein. Tiedot siirtyvät langattomasti tietokantaan ja ovat Internetin kautta käytettävissä lähes reaaliaikaisesti.

Kasvitautiennuste laskee tautiriskin kolmelle viljojen kasvitaudille (verkkolaikku, ruskolaikku, pistelaikku) käyttäen lähtötietoina tilan sääaseman lämpötila- ja sadantatietoja, tilan viljelytietoja (muokkaus, kylvöaika, viljelykierto ja lajike) sekä tautien epidemiologiaa. Ennuste auttaa viljelijää ruiskutustarpeen arvioinnissa ja oikeassa ajoittamisessa. Kahtena kesänä tehdyt mallin testaukset ovat osoittaneet mallin käyttökelpoisuuden ja sen, että paikallinen mittausdata parantaa mallin tarkkuutta.

Kasvinsuojeluruiskutuksen toteuttamisen avustamiseksi rakennettiin työkoneelle tehtävänhallintasovellus ja reaaliaikainen tiedonsiirtoyhteys säätietokannasta työkoneeseen. Sovellus esittää 5 minuutin välein päivittyvän Ilmatieteen laitoksen 3 tunnin sade-ennusteen. Lisäksi testattiin työkoneeseen kiinnitettävää sääasemaa. Työkoneessa reaaliaikaisesti esitetty tieto auttaa huomioimaan säässä tapahtuvat nopeatkin muutokset ja helpottaa mm. tuulivaikutuksen ja varoaikojen huomioon ottamista kasvinsuojeluaineiden levityksessä.

Pilotit demonstroivat automaattisesta mittauksesta sekä erilaisten tiedonlähteiden ja tietoalustojen yhdistämisestä aiheutuvia hyötyjä viljelytoimenpiteiden toteuttamisessa. Hyötyjä syntyy tiedon ajantasaisuudesta ja lohkokohtaisesta mittaamisesta, mutta haasteita aiheuttavat $\mathrm{mm}$. tiedon ajallinen ja spatiaalinen kattavuus sekä tiedon laadunhallinta. Kasvinsuojeluennusteessa käytettiin tilan sääasemalle vaihtoehtoisena tiedonlähteenä Ilmatieteen laitoksen hila-aineistoa. Luotettavat mittaussarjat edellyttävät, että asemien huollosta huolehditaan ja mittausten laatua arvioidaan. Muissa meneillään olevissa hankkeissa pyritään jatkossa lisäämään mittaustiedon käytettävyyttä mm. rajapintojen ja webbipalveluiden avulla.

Asiasanat: jatkuvatoiminen mittaus, automaattiset mittalaitteet, sääasemat, kasvinsuojelu, kasvitaudit 


\section{Johdanto}

Anturiteknologian ja langattoman tiedonsiirron nopea kehitys ja yleistyminen ovat uudistaneet sää- ja ympäristöolosuhteiden tilakohtaista mittaamista ja seurantaa. Yhdistämällä tietolähteitä ja mallintamista voidaan mittaustietoa jalostaa vastaamaan tiedontarvitsijan tarpeisiin myös peltoviljelyssä (Thessler et al. 2011).

Säähavainto- ja ennustetietoja voidaan tarvita niin pellolla kesken töiden kuin toimistollakin. Viljelijä pystyy tekemään päätöksensä paremmin informoituna, kunhan havaintotieto ympäristöstä on saatavilla oikeaan aikaan ja oikeassa paikassa - ja oikealla tavalla jalostettuna. Lämpötila-, tuuli- tai maankosteusanturin tai sademittarin tuottama mittaustieto saattaa jo sinällään olla arvokasta viljelijälle. Mittauksiin pohjautuvat hälytyspalvelut lisäävät tiedon käyttökelpoisuutta. Lisää käyttömahdollisuuksia avautuu, kun paikallinen, reaaliaikainen mittaustieto yhdistetään taustalla toimiviin malleihin kuten kasvitautiennusteisiin. Toimiva tiedonsiirto yhdistettynä seurannan automaattisuuteen ja reaaliaikaisuuteen auttavat myös reagoinnissa muuttuviin olosuhteisiin ja äkillisiin tilanteisiin.

Kasvitaudit aiheuttavat vuosittain huomattavia satotappioita, ja niiden torjunta on merkittävä kustannuserä viljatiloilla. Ajantasainen tieto tautien esiintymisriskistä auttaa kohdistamaan torjunnan vain todelliseen tarpeeseen ja välttämään sekä turhaa työtä ja kustannuksia että ympäristöön kohdistuvaa painetta. Koska useiden viljan tautien kehittyminen on melko säännönmukaista sääolosuhteiden suhteen, voidaan mallinnuksella ennakoida tautien puhkeamista jo ennen kuin tartunta havaitaan kasvustosta. Myös kasvinsuojeluruiskutuksen toteutus on vahvasti riippuvaista sekä toteutushetken olosuhteista että odotetusta sään vaihtelusta. Näistä syistä kasvinsuojelu tarjoaa erinomaisen kokonaisuuden reaaliaikaisen mittaustiedon hyödyntämisen ja päätöstuen tarjoamisen tutkimiselle.

Tässä artikkelissa tarkastellaan pilottisovellusten avulla säähavainto- ja sääennustetiedon käyttöä ja tiedonsiirtoa kasvinsuojelun päätöstukisovelluksissa. Työssä esitellään kaksi pilottia: 1) kasvitautiriskiennusteiden tarkentaminen paikallisesti mitatulla säähavaintotiedolla sekä 2) on-line säätiedon tuominen kasvinsuojeluruiskun tehtävänhallintaan.

Työ tehtiin Maa-ja metsätalousministeriön rahoittamassa Envisense-hankkeessa, jossa kehitettiin automaattisesti tuotetun ympäristön mittaustiedon käyttöä maatalouden sovelluksissa. Hanketta koordinoi MTT kumppaneinaan SYKE ja Ilmatieteen laitos.

\section{Aineisto ja menetelmät}

Työssä hyödynnettiin Karjaanjoen valuma-alueelle 2007 - 2008 rakennettua Maasäähavainnointiverkkoa (Huitu 2009). Lisäksi sääasemia pystytettiin Hämeeseen, Pohjanmaalle ja läntisen Uudenmaan rannikolle. MTT:n ja Suomen ympäristökeskuksen omistama Maasää-verkko koostuu yli 50 sääasemasta sekä paristakymmenestä veden laadun mittauspisteestä. Asemat tuottavat mittauksia 15 min - tunnin välein, ja mittaukset ovat saatavilla web-palvelusta käyttöön lähes reaaliaikaisina. Paikallisesti mitatun tiedon lisäksi käytössä oli Ilmatieteen laitoksen tuottamaa hilatietoa, sekä paikallista sääennustetietoa.

Pilotit demonstroivat automaattisen sään seurannan hyötyjä sekä erilaisten tiedonlähteiden ja tietoalustojen hyödyntämismahdollisuuksia kasvinsuojelun toimenpiteiden toteuttamisessa.

Kasvitautiennuste laskee tautiriskin kolmelle viljojen kasvitaudille (verkkolaikku, ruskolaikku, pistelaikku) käyttäen lähtötietoina lämpötila- ja sadantatietoja tilan sääasemasta, viljelytietoja (muokkaus, kylvöaika, esikasvi ja lajike) sekä tautien epidemiologiaa. Ennuste auttaa viljelijää ruiskutustarpeen arvioinnissa ja oikeassa ajoittamisessa. Kasvinsuojeluennusteessa käytettiin tilan sääasemalle vaihtoehtoisena tiedonlähteenä Ilmatieteen laitoksen hila-aineistoa.

Kasvinsuojeluruiskutuksen avustamiseksi rakennettiin työkoneelle tehtävänhallintasovellus sekä reaaliaikainen tiedonsiirtoyhteys säätietokannasta työkoneeseen. Työkoneessa reaaliaikaisesti esitetty tieto auttaa huomioimaan säässä tapahtuvat nopeatkin muutokset ja helpottaa mm. tuulivaikutuksen ja varoaikojen huomioon ottamista kasvinsuojeluaineiden levityksessä.

Traktori-kasvinsuojeluruiskuyhdistelmä käytti työn toteutuksessa MTT:n ja Aalto-yliopiston yhteistyönä kehittämää ISOBUS -prototyyppiä. Ruiskun ohjain lataa käyttöliittymänsä traktorissa olevaan ISOBUS yleisterminaaliin, josta kuljettaja voi hallita kaikkia ruiskun ominaisuuksia. Traktoriohjain puolestaan lähettää ISOBUS-väylälle ajonopeustiedon, jota ruisku käyttää säädöissään 
hyväksi. Ruiskuyhdistelmän keskustelu ulkomaailman kanssa hoidetaan ISOBUS-järjestelmään kytketyn prototyyppi tehtäväohjaimen avulla käyttäen 3G/Gprs-yhteyttä. Envisense-hankkeessa PCpohjaiseen tehtäväohjaimeen rakennettiin ja ohjelmoitiin ominaisuudet, joiden avulla kuljettajalle voidaan esittää 5 minuutin välein päivittyvä Ilmatieteen laitoksen 3 tunnin sade-ennuste. ISOBUSkomponenttien lisäksi järjestelmää laajennettiin traktorin katolle asennetulla sääanturilla, jonka mittaustieto näytetään tehtäväohjaimen avulla kuljettajalle.

\section{Tulokset ja tulosten tarkastelu}

\section{Viljojen tautiennusteet viljelijän tukena}

Ennustemalli tukee viljelijää päätöksessään kasvukauden aikaisen torjunnan ajankohdasta ja tarpeenmukaisuudesta. Viljojen lehtilaikkutautien ennustemallissa lasketaan esikasvin, muokkaustavan ja lajikkeen perusteella alkuarvo, joka kertoo taudin esiintymisriskistä lohkolla. Tämän jälkeen malli laskee lohkokohtaisten säätietojen perusteella todennäköisyyden itiöiden muodostumiselle, leviämiselle sekä infektiolle. Taudinaiheuttajan kehittyminen kasvustossa vaikuttaa taudin leviämiseen. Malli ottaa tämän huomioon sekä laskennallisesti tai syöttämällä tehty kasvitautihavainto. Tästä saadaan laskettua päivittäinen riskiarvo.

Hankkeessa kehitettiin ennustemallin oikeellisuutta sekä testattiin hiladatan käyttökelpoisuutta tilakohtaisten sääasemien vaihtoehtona mallin säätiedon lähteenä. Ennustemallin epidemiologinen osio edellytti tarkennusta taudinaiheuttajien etenemisestä Suomelle tyypillisessä viileässä alkukesässä. Infektiokokeiden perusteella Suomen ohrapeltojen yleisin taudinaiheuttaja ohranverkkolaikku (Pyrenophora teres) etenee kasvustossa, vaikka päivän keskilämpötila olisi alle $5{ }^{\circ} \mathrm{C}$. Riittävässä kosteudessa ensimmäiset taudin leviämisen mahdollistavat itiöt muodostuvat jo 7 vuorokauden kuluttua tartunnasta. Lämpötilan nousu edistää uusien itiöiden muodostusta. Vehnän pistelaikun (Pyrenophora tritici-repentis) eteneminen on viileässä hidasta. Alle $15^{\circ} \mathrm{C}: n$ lämpötilassa oireet kehittyvät verkkolaikkuun verrattuna vain puolella nopeudella. Uusien itiöiden muodostus pääsee vauhtiin, kun keskilämpötila ylittää $10^{\circ} \mathrm{C}$. Runsainta itiönmuodostus on kosteissa olosuhteissa keskilämpötilan ollessa $20^{\circ} \mathrm{C}$.

Lohkokohtaisen säätiedon merkitys korostuu kasvitautien esiintymistä arvioitaessa. Erityisesti kasvustojen kosteudessa on suurta vaihtelua eri lohkojen välillä. Kasvukausina 2010-2011 viljojen kasvitautien ennustemallia testattiin 18 viljelijän ja maatalousoppilaitoksen lohkolla. Näistä kymmenellä oli käytettävissä sääasema. Ilmatieteen laitoksen kehittämä neliökilometrin tarkkuudella saatava säätieto todettiin pääosin riittäväksi kasvitautien ennustemallien toimivuuden kannalta. Ongelmallisinta oli kuuroittaisten sateiden arviointi. Merkittävin ympäristötekijä taudinaiheuttajan infektiossa on lehden kosteus. Tämä arvioidaan ilman suhteellisesta kosteudesta, jonka tiedon tuottamisessa hila-data oli hyvin lähellä lohkokohtaista sääasemaa. Muuntuvissa olosuhteissa, muuntuvilla taudinaiheuttajilla ennustemalli edellyttää jatkuvaa kalibrointia.

\section{Säätieto kuljettajan päätöksenteon tueksi}

Avustettua ohran tautiruiskutusta pilotoitiin MTT:llä Vihdissä kesällä 2011. Kasvitautien ennustepalvelu lähetti tautiruiskutuskehotuksen viljelijän kännykkään, jonka jälkeen ruiskutussuunnitelmat päivitettiin lohkoille kasvuston tilan, sääasematietojen ja sääennusteiden perusteella. Ruiskun tankkausvaiheessa kuljettaja käytti paikallissääasemien säätietoja ja Ilmatieteen laitoksen kolmen tunnin paikallissääennusteita hyväkseen (Kuva 1). Ruiskutuksen aikana kuljettaja tarkkaili tuulen nopeutta, ilman lämpötilaa ja kosteutta tehtäväohjaimeen kehitetyn sääkäyttöliittymän avulla. Tietojen avulla kuljettajalla oli mahdollisuus säätää ruiskutuspainetta/pisarakokoa ajonopeutta muuttamalla niin, että pisaroiden tuulikulkeuma minimoitiin. Ruiskutuksessa kuljettaja käytti Ilmatieteen laitoksen paikallissääennustetta hyväkseen päätöksenteossa ruiskutuksen jatkamisesta ottaen huomioon eri aineiden vaatimat sateenkestävyysrajat. Kun ruiskutustyö oli tehty, kuljettajalla oli mahdollisuus lähettää dokumenttitiedosto tehdystä ruiskutustyöstä joko tautiennustepalvelulle tai ruiskutuspalvelun ostajalle. 


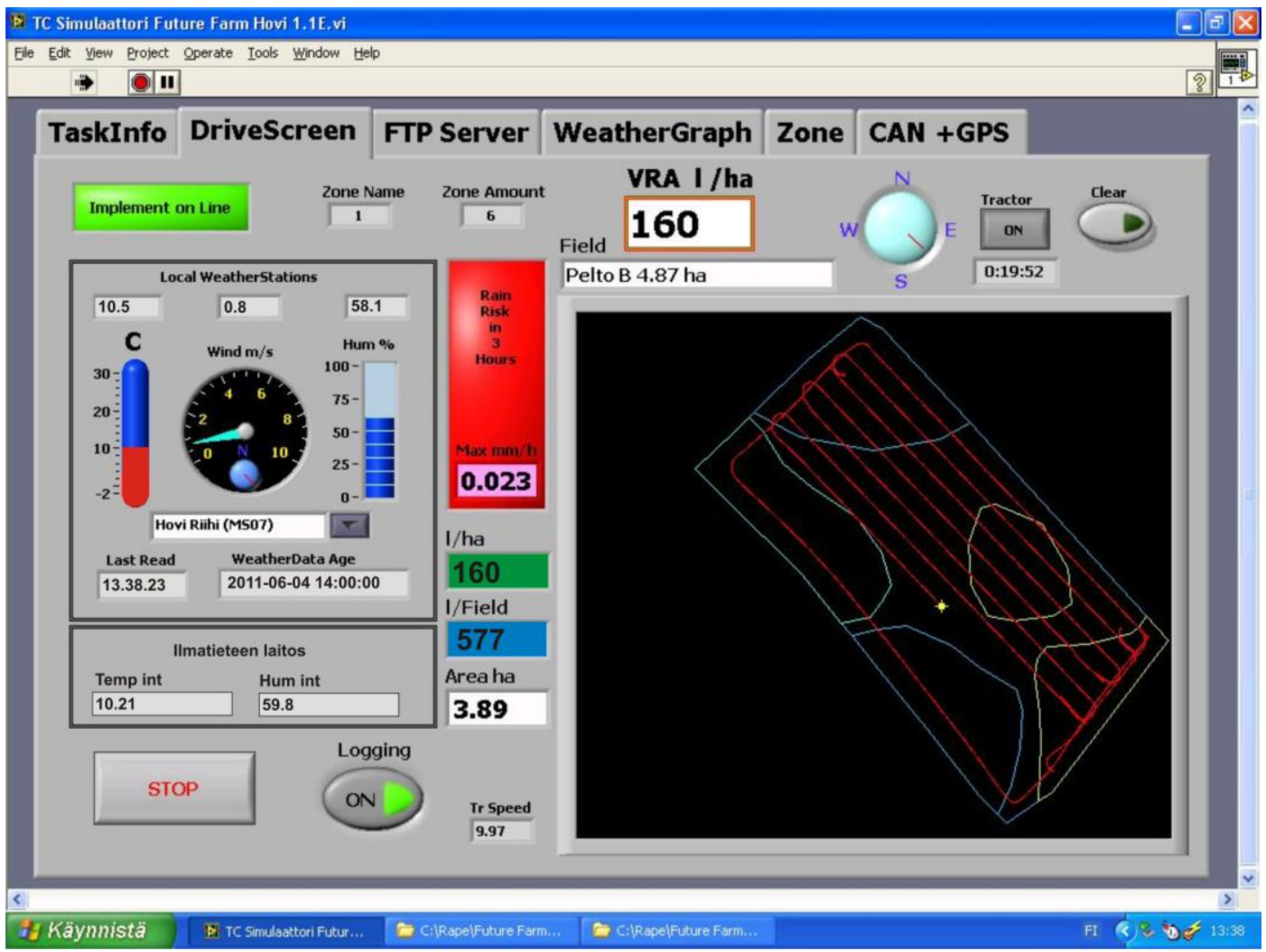

Kuva 1. Säätiedot esitettiin kuljettajalle PC-pohjaisen tehtäväohjain prototyypin avulla

\section{Johtopäätökset}

Kahtena kesänä tehdyt ennustemallin testaukset ovat osoittaneet mallin toimivuuden ja sen että paikallinen mittausdata parantaa mallin tarkkuutta. Luotettavat mittaussarjat kuitenkin edellyttävät, että asemien huollosta huolehditaan ja mittausten laatua arvioidaan.

Ympäristönmittaustiedon monipuolinen ja tehokas käyttö maatilalla helpottuu, kun yhteydet viljelysuunnitteluohjelmaan tai muuhun tilan tietojärjestelmään toimivat. Tietojen yhteiskäyttöä tukevia standardeja ja teknologisia ratkaisuja on olemassa, mutta niitä ei ole vielä otettu kattavasti käyttöön. Kun toimijoita on useita, tietojen jouheva ja häiriötön kulku järjestelmästä toiseen ei ole mikään itsestäänselvyys.

Paikallisäätietojen ja -sääennusteiden käyttö kasvinsuojeluruiskutuksissa helpotti kuljettajan päätöksentekoa. Haasteena koettiin langattomien tiedonsiirtoyhteyksien nopeus ja luotettavuus erityisesti pelto-olosuhteissa. Uudet internet-teknologiat ja automaation lisääntyminen työkoneissa tulevat helpottamaan kuljettajan toimintaa. Lähitulevaisuuden traktori-ruiskuyhdistelmät tulevatkin hyödyntämään paikallissääasemien tuottamaa tietoa ja sääennusteita ruiskun automaattisessa ohjaamisessa.

\section{Kirjallisuus}

Thessler, S., Kooistra, L., Teye, F., Huitu, H., Bregt, A. K. 2011. Geosensors support crop production : current applications and users requirements. Sensors 11, 7: 6656-6684. doi: 10.3390/s110706656 [Url] 27.6.2011

Huitu, H. 2009 (toim). Automatisoidun mittausverkon kehittäminen ympäristön seurantaan. MTT Kasvu 8: $58 \mathrm{~s}$ 